\title{
From Alienism to the Birth of Modern Psychiatry: A Neurological Story?
}

\author{
Julien Bogousslavsky ${ }^{a}$ Thierry Moulin ${ }^{b}$ \\ a Department of Neurology and Neurorehabilitation, Clinique Valmont, Genolier Swiss Medical Network, \\ Glion, Switzerland; ${ }^{b}$ Department of Neurology, Hôpital Jean Minjoz, Besançon, France
}

\section{Key Words}

Neuropsychiatry $\cdot$ History of psychiatry $\cdot$ History of neurology $\cdot$ Charcot, Jean-Martin

\begin{abstract}
The interactions between developing neurology and psychiatry in Paris are of interest, in a city which was the main center for studies on the nervous system and its disorders during the nineteenth century. Contrary to a common view, and in spite of an established tradition for mental diseases, emerging neurology had a much stronger influence on psychiatry ('alienism') than the reverse. This was largely due to the school built up by Jean-Martin Charcot, which was organized around the study and management of hysteria. Although Charcot himself always claimed his disinterest in mental medicine, he stimulated the development of an original scientific approach to nervous system conditions, along with a structured academic teaching, while alienism paradoxically remained stuck in organicism, after Antoine Bayle's report in 1822 of 'arachnitis' as the substratum of general paresis of the insane. Contrary to alienism, the young neurological school was able of self-criticism, and progressively underscored mental factors in hysteria. This led to the paradox that neurologists were active in a disease with a recognized lack of organic lesion, while alienists were postulating brain lesions in all mental disorders. The neurological activity thus indirectly and involuntarily led to the first develop-
\end{abstract}

ments of psychodynamic concepts in mental diseases. The academic evolution led to the launch of a faculty chair of mental and brain diseases in 1875 , which was taken over for nearly half a century by direct pupils of Charcot: Benjamin Ball, Alix Joffroy, and Gilbert Ballet held the position until 1916 , supporting the development of modern psychiatry in general hospitals, while alienism progressively disappeared at the turn of the century.

Copyright $\odot 2009$ S. Karger AG, Basel

While the term 'neurology' was coined by Thomas Willis during the second part of the seventeenth century, the field and development of neurology is a rather young domain of clinical medicine. In France, neurology specialists were called 'neurologistes' only in 1896, and 'neurologues' in 1907 [1]. This relative youth is in contrast with the ancient roots of psychiatry, although that term is also of rather recent use, after its introduction by Johann Christian Reil ('Psychiaterie') at the end of the eighteenth century [2]. In France, the terms 'fou' and 'folie' (mad, madness) date back to the 'Chanson de Roland' around 1080 , while the more modern concept of 'mental alienation' developed in the fourteenth century, leading to the identification of specialist physicians as 'alienists' at the beginning of the nineteenth century [1]. In France, the term 'psychiatre' (psychiatrist) was accepted by the Académie in 1802, but its use became widespread only one

\section{KARGER}

Fax +4161306 1234 E-Mail karger@karger.ch www.karger.com
(C) 2009 S. Karger AG, Basel

0014-3022/09/0625-0257\$26.00/0

Accessible online at:

www.karger.com/ene
Julien Bogousslavsky

Department of Neurology and Neurorehabilitation

Clinique Valmont, Genolier Swiss Medical Network

CH-1823 Glion (Switzerland)

Tel. +41 2196237 01, Fax +41 2196238 38, E-Mail jbogousslavsky@valmontgenolier.ch 
century later, while the term 'aliéniste' was becoming obsolete. Because of theses differences in development, along with the much deeper historical origins of madness and its management, it is commonly accepted that psychiatry widely influenced the development of the younger neurology.

However, it must be emphasized that it is difficult to review historical developments of medicine with terms which were not used at the time. Indeed, these terms precisely developed in connection with the evolution of corresponding concepts and practice in the related field. Moreover, the historical developments were not identical from country to country. In France, which is classically considered as the cradle of clinical neurology in the nineteenth century, a thorough review of historical landmarks strongly suggests that in contrast to common views, the influence of neurology on psychiatry was much stronger than the reverse, while neurology mainly emerged from 'clinique médicale' (the precursor of internal medicine) and pathology during the second half of the nineteenth century.

\section{The Birth of Neurology at La Salpêtrière: The Role of Hysteria}

While the use of the term 'neurologie' became usual in France only during the first years of the twentieth century, the corresponding concept already encompassed the varied diseases of the nervous system, the identification of which led to the establishment of the chair of 'clinique des maladies du système nerveux' (diseases of the nervous system) in 1882 at the Faculty of Medicine in Paris. The chair was created for Jean-Martin Charcot (1825-1893), who was the driving force of the new specialty at La Salpêtrière, and who had been named professor of pathological anatomy ten years before [3]. Charcot had written his thesis on gout in 1853, and he got a professorship (agrégation) in 1860, after an unsuccessful attempt. He arrived at La Salpêtrière at the end of 1861, taking charge of his inpatients service on January 1st, 1862 [4]. Charcot had absolutely no connection with the mental alienation tradition and school of Pinel and Esquirol, and he always claimed his lack of interest in mental medicine, while he never joined the Société MédicoPsychologique [5]. Apart from Désiré Bourneville, Charcot also never selected his internes and chefs de clinique with a background in mental alienation. It is striking that the year of Charcot's thesis, no teaching chair of what one would now call neurology and psychiatry was present in the Faculty of medicine. The great names of the time included Cruveilhier (pathological anatomy) and Trousseau and Bouillaud (clinical medicine). In his 1853 doctorate thesis [6], the only mentor quoted by Charcot with some connection with the nervous system was Jules Baillarger, who had been working as an alienist at La Salpêtrière for over a decade.

Charcot's work initially developed on general medical issues, with thorough pathological assessment. While it soon focused on diseases affecting the nervous system (Parkinson's disease, multiple sclerosis, amyotrophic lateral sclerosis, hereditary peripheral neuropathy, tabes), it is striking that the unity of his school took place around the study of hysteria, which played a federating role. In the 1860s, hysterical women with somatic manifestations were commonly admitted to La Salpêtrière, and they formed a large part of the Delasiauve service, along with epileptics [4]. When the Delasiauve service was dismantled in 1870, because of building work in the hospital, Charcot became responsible of the hysterics and epileptics. Probably with the advice of his interne Bourneville, who had some experience in mental conditions, Charcot started to study these women, in whom nobody seemed particularly interested. Indeed, while internists discarded this disease after Paul Briquet (1796-1881) had definitely eliminated an underlying pathology of the uterus [7], hysteria never was a topic of major interest among the alienists in Paris, who at the time were focusing on what one now calls psychoses. It is very likely that part of the disinterest of the alienists was due to the physical manifestations of hysterics, which actually suggested organic focal brain diseases. It is interesting that much later, after hysteria left organic neurology to be included into psychiatric pathology at the beginning of the twentieth century, patients still continued to be first referred to neurologists, precisely because of the 'neurological-looking' clinical manifestations.

Charcot and his pupils quickly occupied the medical no man's land of hysteria, introducing susceptibility to hypnotism as one of the criteria to the diagnosis, together with sensory and motor 'stigmatas' [8]. To deal with the absence of morphological lesion in the brain, Charcot developed the concept of a 'dynamic lesion', which could not be seen under the microscope. In doing so, he was considering hysteria as an organic disease similar to any organic disease of the nervous system, and the issue of psychological factors appeared in his work only shortly before his death in 1893 [5]. In the preface to Pierre Janet's 'The mental state of hysterics' [9], Charcot wrote that hysteria is 'largely a mental disease', but this was a concept 
which would crystallize only later, mainly with Pierre Janet himself, and with Sigmund Freud. This evolution was critical in stimulating the first developments of psychodynamic concepts and models, which at the time were out of the scope of alienism. In studying hypnotism and the mental state of hysterics, Charcot's followers (mainly Georges Gilles de la Tourette, Paul Richer, Joseph Babinski, Paul Sollier and Pierre Janet) implicitly recognized the importance and power of the 'unconscious', even though it was not immediately called as such. They emphasized the underground work of memory, which stored certain mental experiences in a way that they are not accessible through the will or conscious efforts of retrieval. In his doctorate thesis [10], Janet concluded that hysteria is characterized by a constant splitting ('dédoublement') of personality, each part ignoring the other one, in a 'shrinkage of consciousness'. It is striking that while the concept of the unconscious was also discussed in philosophical circles at the time (Nietzsche, etc.), its first developments in the medical field occurred in neurology, and not within the representants of mental alienation. And it is only after Babinski revised Charcot's concept of hysteria, between 1901 and 1908, and when Janet highlighted that it was not possible anymore to consider hysteria as an organic brain disease, that the issue of a 'hysteric personality' really emerged and became a study topic for psychiatry [11]. In 1911, Gilbert Ballet, who was the third holder of the chair of 'clinique de pathologie mentale et des maladies de l'encéphale' (mental and brain diseases), rejected Jules Dejerine's claim (second successor to Charcot's chair, but a pupil of Vulpian, not of Charcot) that Charcot had captured the field of hysteria for neurology by 'taking it away from psychiatrists' [5]. The situation was indeed comically paradoxical, since Ballet represented academic psychiatry, but was also a direct pupil of Charcot, while Dejerine was the leading figure of academic neurology, but had never been a pupil of Charcot. In fact, Charcot never had to capture hysteria from the alienists, since they had always claimed their disinterest for that condition at the time. Étienne-Jean Georget (1795-1828), one of the most distinguished alienists in the beginning of the nineteenth century, had written that hysteria belonged to the brain [12], as Charles Le Pois had first claimed at the beginning of the seventeenth century, but it did not belong to mental alienation, because 'there is no madness without delirium' (the term of 'psychosis' was first coined by Ernst von Feuchtersleben in 1845) [2]. After Charcot, hysteria slowly took its place in a newly identified group of mental diseases, the 'psychoneuroses' (the term of 'neurosis' had first been proposed by William
Cullen in Edinburgh in 1769) [2], to differentiate them from the 'vésanies' (psychoses) of the alienists, joining in the same nosographic group neurasthenia of George Baird (1879), the psychoneuroses of defense of Sigmund Freud (1894), and psychasthenia (obsessive neurosis) of Pierre Janet (1903).

\section{The Birth of Modern Psychiatry: The Critical Influence of Emerging Neurology}

The early developments of French neurology were really due to the efforts of a single man, Jean-Martin Charcot, who soon was surrounded by an impressive number of pupils. The field of what we now call psychiatry had a completely different evolution. Its first modern 'revolution' was associated with the activity of Philippe Pinel (1745-1826), who established a clear distinction between 'alienated patients' and vagabonds, beggars, and other marginal people. His treatise on mental alienation and mania was published in 1801 [13], with an impact beyond the medical world, on philosophers and writers, such as Hegel, Maine de Biran and Stendhal. Pinel worked at Charenton and Bicêtre, before La Salpêtrière, where his most famous follower Jean Étienne Dominique Esquirol (1772-1840) joined him in 1811. Esquirol worked on hallucinations and made a major report in 1819 to the ministry on public institutions for alienated patients. Three years later, under the chairmanship of Antoine Athanase Royer-Collard (1768-1825), chief physician at Charenton and first holder of an official professorship on mental disorders in Paris in 1819, Antoine Laurent Jessé Bayle (17991858) presented his doctorate thesis on 'Research on mental diseases' [14], which would become one of the most important papers in the history of psychiatry: he showed that a form of dementia, general paresis of the insane, was associated at autopsy with a meningo-encephalitis, which he called 'arachnitis'. While it was only in 1879 that Jean Alfred Fournier (1832-1914) would demonstrate the syphilitic origin of the process [15], Bayle's report really was revolutionary in that it linked without doubt mental alienation with an organic brain abnormality. The effect was rather dramatic, because it triggered a frenzy of reports associating virtually all forms of mental disorders with brain lesions, leading to a triumph of organicism [2], where the alienists Jacques Joseph Moreau de Tours (1804-1884), a pupil of Esquirol, and Bénédict Augustin Morel (1789-1873), a former room-mate of Claude Bernard, played a leading role. Morel's 'degenerescence' (1857) theory was developed to explain cases in which no 


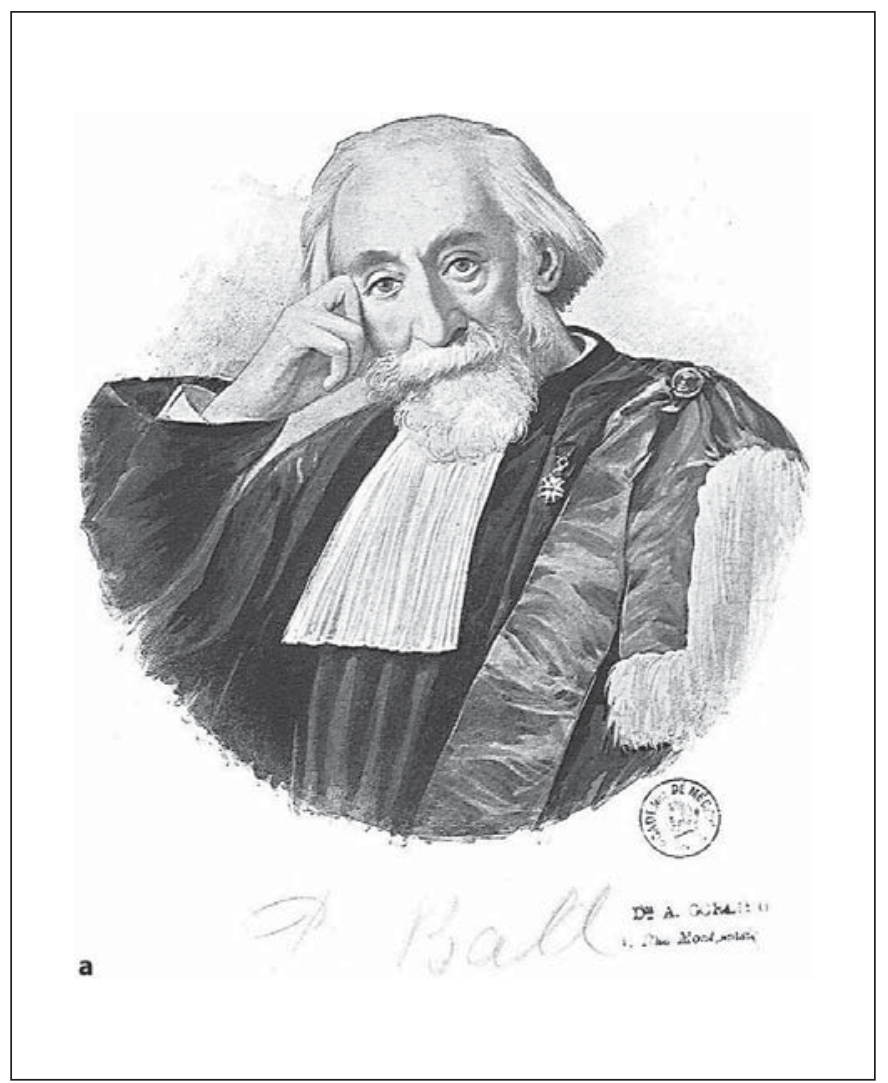

Fig. 1. The first holders of the only chair of mental and brain diseases at the Paris Faculty of Medicine, established in 1875 (opening in 1877), were all pupils or collaborators of J.-M. Charcot. a Benjamin Ball (1833-1893), holder from 1877 to 1893. b Alix Joffroy (1844-1908), holder from 1894 to 1908, after an interim by Gilbert Ballet. c Gilbert Ballet (1853-1916), holder from 1909 to 1916.

obvious anatomical lesion was seen at autopsy, and in that it followed the same path as Charcot's 'dynamic lesion' for hysteria twenty years later. It is indeed striking that while emerging neurology was focusing on a brain disease without a brain lesion (hysteria), the alienists were trying to explain all cases of madness with brain lesions. In parallel, an important step was made under the influence of Jean-Pierre Falret (1794-1870), who headed the Hospice de la Salpêtrière during 36 years (1831-1867): he switched from the concept of a unique form of mental alienation with the four different symptoms established by Pinel and Esquirol (mania, melancholia, monomania, dementia) to several, distinct 'mental diseases', also introducing evolution in the definition of the different forms of alienation [2].

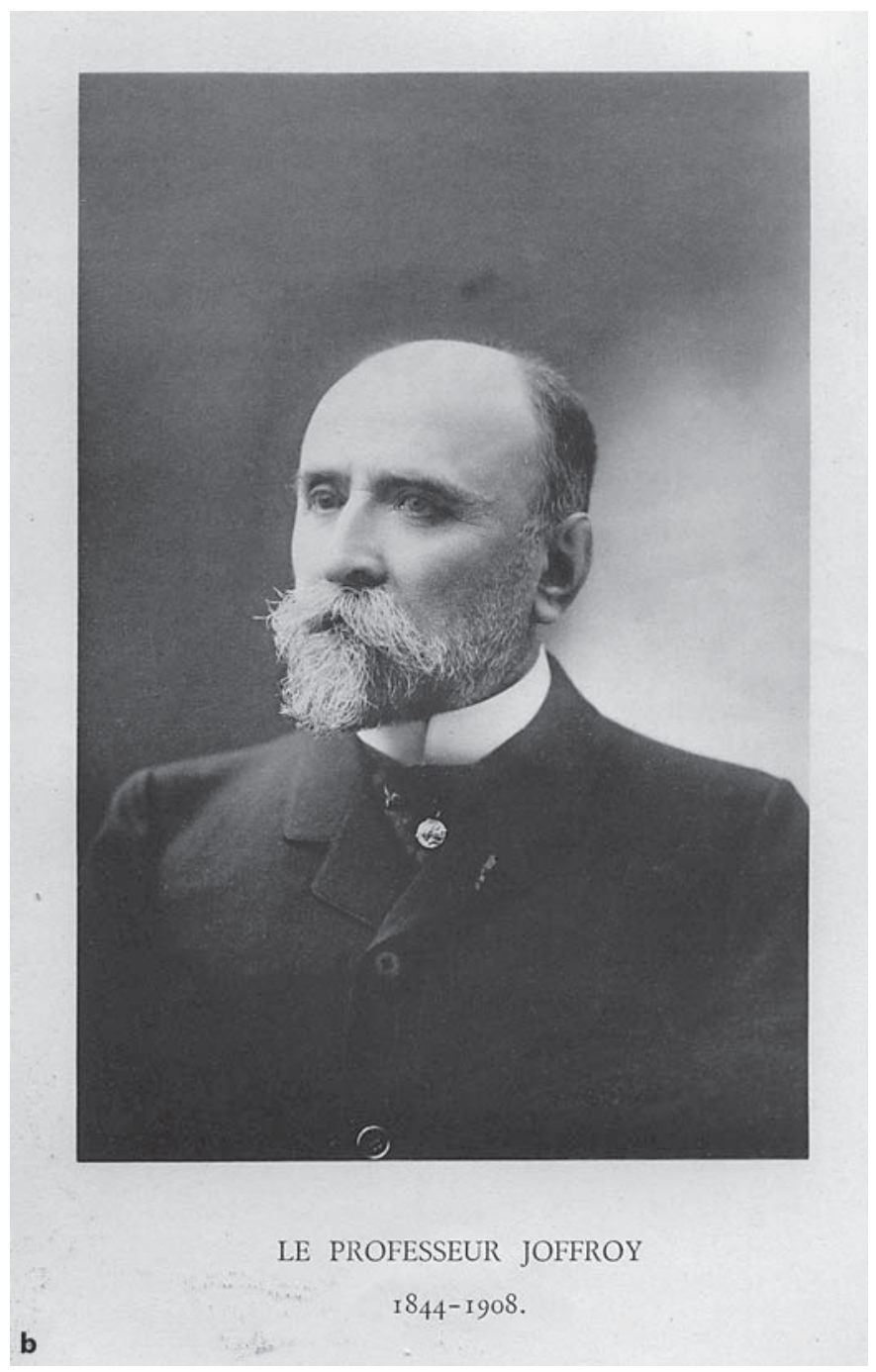

A major problem for the alienists was the fact that they mainly remained centered on managing patients, but did little research and scientific teaching, features which were exactly the qualities that Charcot was attempting to insufflate to his own school, following the contemporary concept of Claude Bernard's experimental medicine. And it was no surprise that when the creation of a chair for mental diseases was decided by the Faculty of Medicine in 1875, it was not one of the established alienists of the time who was chosen, but Benjamin Ball (1833-1893) (fig. 1a), a former assistant of Lasègue, who had also worked with Charcot, with whom he had published a report on sudden death from pulmonary embolism in 1858 [16]. Ball won the contest over Valentin Magnan (18351916), who was chief physician at Sainte-Anne, and represented the hard line of the alienists tradition. Since the 


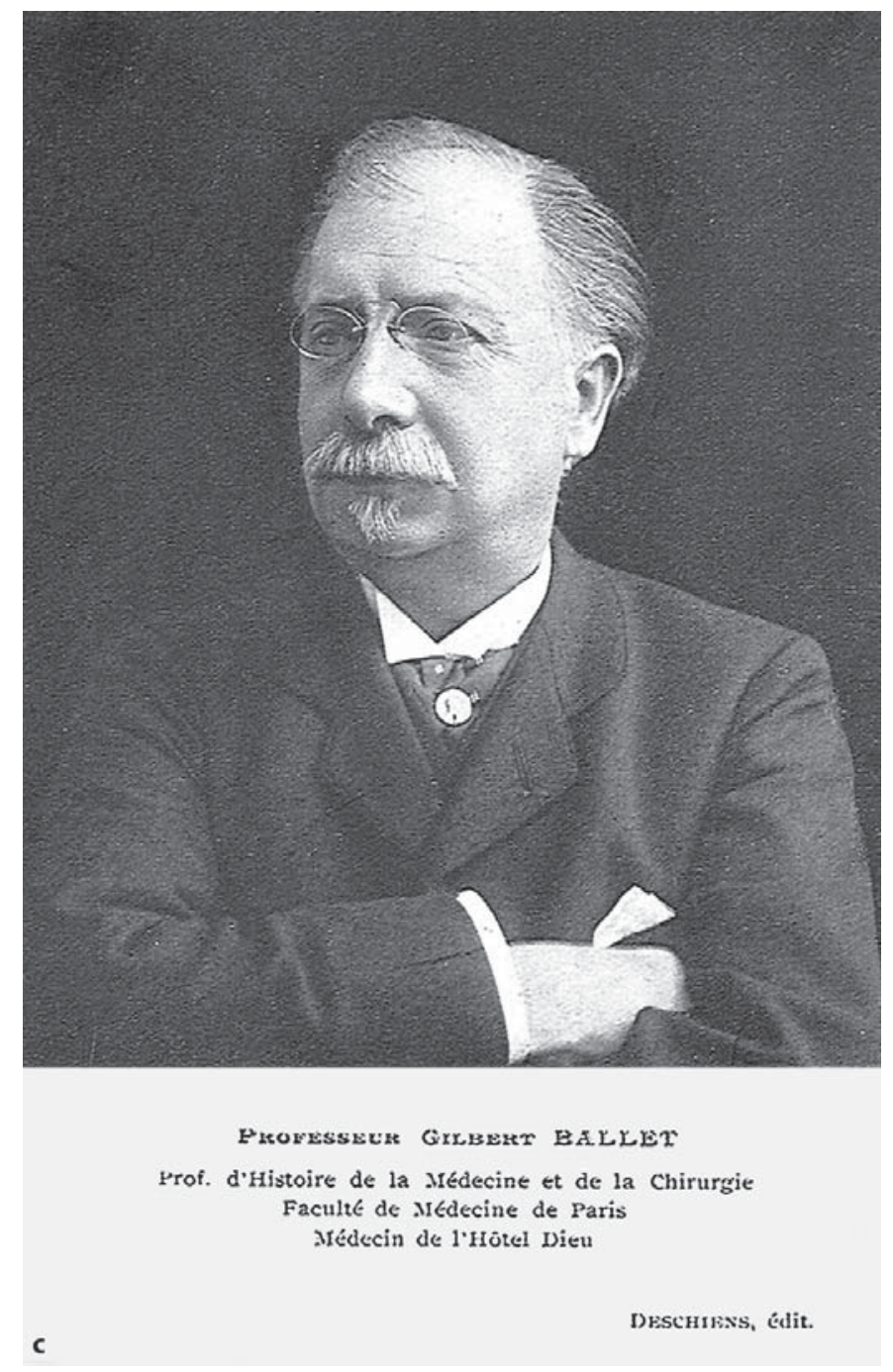

chair (opening in 1877) was based at Sainte-Anne, but Ball's service was in another hospital at Laënnec while Magnan remained chief of service at Sainte-Anne, it is easy to imagine the conflicts and intrigues which may have taken place during the following years. But when Ball died in 1893, his successor was not Magnan, who applied again, but Alix Joffroy (1844-1908) (fig. 1b), who had absolutely no experience as an alienist, but was a close pupil of Charcot, and was heading the second service of neurology at La Salpêtrière (the 'Jacquart' service, while Charcot was in charge of the 'Cazalis' service) [17]. He had also worked with Duchenne and Vulpian, the two other leading figures of emerging neurology. Gilbert Ballet (1853-1916) (fig. 1c), another close pupil of Charcot, of whom he had been 'chef de clinique', became the third holder of the chair in 1909, and his appointment really corresponded to the disappearance of nineteenth century alienism, with the emergence of modern psychiatry. It is significant that for the first 40 years the only chair for mental diseases at the Paris Faculty was hold by immediate pupils of Charcot, who had little or nothing to do with the tradition of alienism in mental hospitals and services. This neurological influence on the birth of academic psychiatry is also well shown by the fact that Joffroy and Ballet both became presidents of the Society of Neurology (founded 1899) and the Society of Psychiatry (founded 1908), Joffroy being even the first president of each society [18].

\section{Neuropsychiatrists}

The close association of neurologists with the development of modern psychiatry has been one of the reasons for the presence of 'neuropsychiatrists' during at least two thirds of the twentieth century, before they disappeared under the criticism of being neither neurologists nor psychiatrists. However, the tradition of neuropsychiatrists went back to the nineteenth century, as exemplified by the career of two famous physicians, Jules Gabriel François Baillarger (1809-1890) and Ernest Charles Lasègue (18161883) (fig. 2, 3). Both were established alienists, who also did major contributions in other domains of the nervous system, and the fact that they were slightly older than Charcot certainly contributed to their tolerance by the emerging neurological school. Baillarger had written a famous doctorate thesis on subarachnoid hemorrhage in 1837 [19], and was appointed alienist at La Salpêtrière in 1840, before he founded in 1843 the Annales Médico-Psychologiques with Cerise and Longet, the 'journal of mental alienation and of legal medicine of the alienated', which has appeared without interruption until today. He also stimulated thelaunch of theSociétéMédico-Psychologique in 1852. Baillarger's main contributions in mental diseases were his studies on hallucinations and his description in 1854 of 'madness with double form', the same year as Lasègue and Falret's 'circular madness', the ancestor of manic-depressive psychosis [2]. He also remained famous in neurology in relation to his precise description of cortical layers and their connections with the underlying white matter [20]. Baillarger generally remained faithful to the ideas of his mentor Esquirol, but he evolved sufficiently on the new concepts of mental disease to be offered the first faculty chair of mental and brain diseases in 1875, which he declined, because of his age, leaving the position to Benjamin Ball. Charles Lasègue was one of the most 


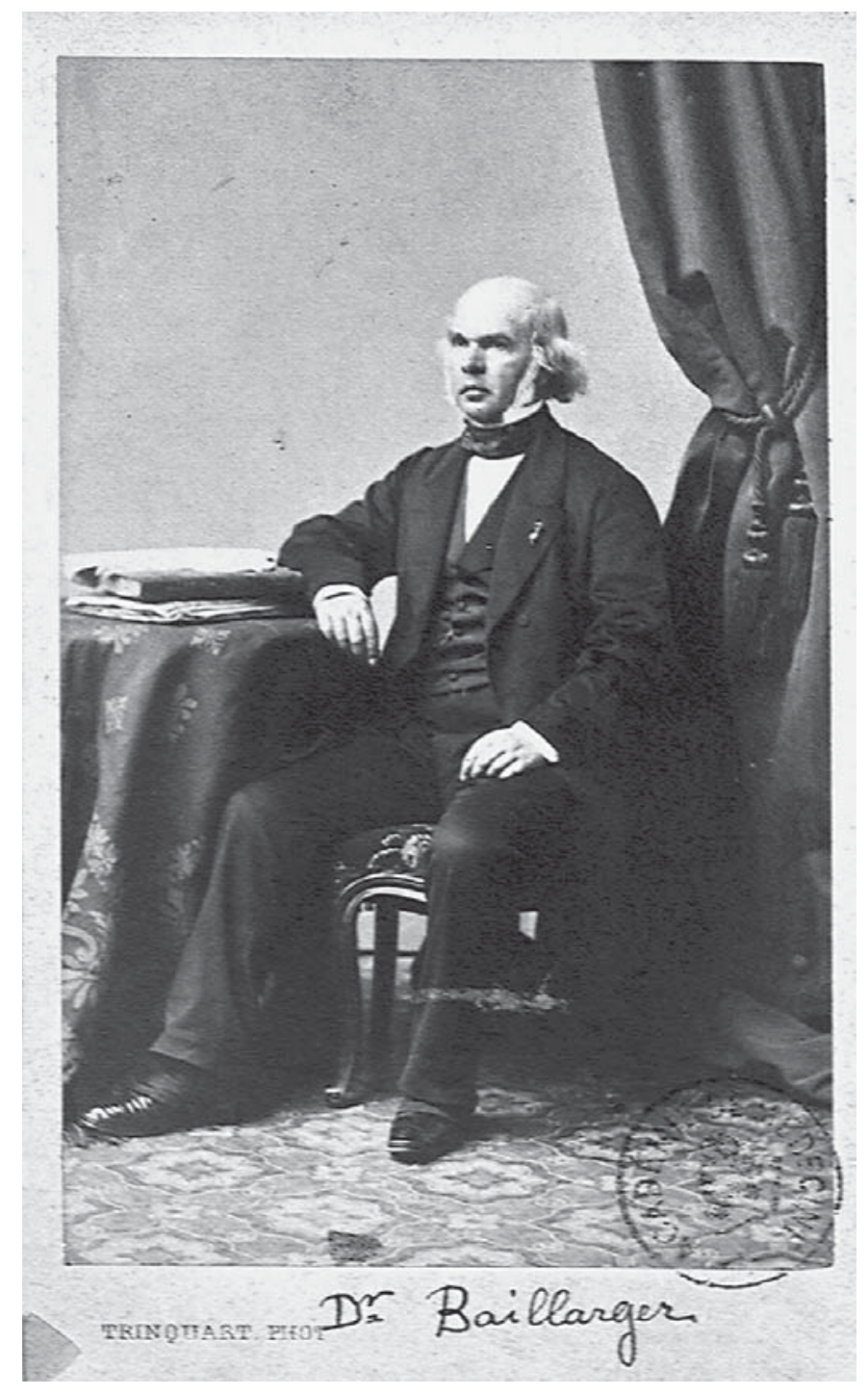

Fig. 2. Jules G.F. Baillarger (1809-1890) can be considered the first neuropsychiatrist. Beside his contribution to alienism, he wrote his thesis on subarachnoid hemorrhage in 1837 and made the first description of the cortical layers in 1840 .

brilliant physicians of the century. After philosophical studies and a teaching period at the Louis-le-Grand college where the poet Charles Baudelaire was one of his pupils [21], he switched to medicine and became a close friend of Claude Bernard, who introduced him to Falret, before he became 'chef de clinique' of Trousseau at HôtelDieu. In 1853, the year when Charcot and Vulpian presented their doctorate thesis, he wrote his professorship thesis on general paresis [22]. He also made the first reports on 'persecution delirium' and 'circular madness', before he was asked in 1862 to deliver the first official se-

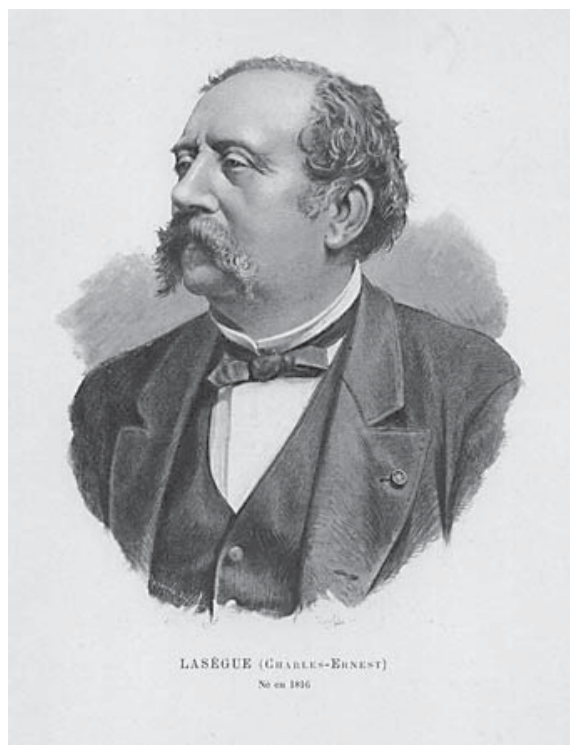

Fig. 3. E. Charles Lasègue (1816-1883) was probably the most brilliant physician of his time in Paris, which enabled him to encompass both established alienism and emerging neurology.

ries of faculty lectures on mental pathology, being appointed full professor of general pathology in 1867, and chairman of clinical medicine at La Pitié in 1869 [2]. He was also the first physician of the 'dépôt municipal des aliénés', which would become the celebrated unit of the 'infirmerie spéciale de la préfecture de police', where Ball, the future first holder of the chair for mental and brain dieases, worked for a time as his assistant. The name of Lasègue is of course associated with his 'sign' in lumbar root compression, although the written report was made by his assistant Forst in 1881 [22]. Lasègue developed an interesting activity in hysteria in parallel to that of Charcot: he was one of the first to emphasize the hysterical 'character', in 1881, and made the first description of hysterical anorexia in eight cases in 1873 [3]. Contrary to Charcot, he stated that hysteria could not be defined in the same way as other diseases of the nervous system, because it was associated with an infinity of manifestations, predicting that its future should be in mental medicine.

However, apart from Baillarger and Lasègue, there were few alienists who contributed to the study of nervous system diseases, perhaps except Achille Foville (1799-1878), who was the successor to Esquirol at Charenton, but who also made significant works on brainstem lesions and epilepsy [24]. After the time of Charcot, Baillarger and Lasègue, a few neurologists continued to follow patients in neuropsychiatric consultations, includ- 
ing Jules Déjerine and Paul Sollier, who were famous for their 'isolation cure' in neurasthenia [25], the novelist Marcel Proust being one of the most famous patients [26]. The concept of neuropsychiatry was also maintained by the Great War, because of the close collaboration between neurologists (Dejerine, Gustave Roussy, Babinski, Sollier) and psychiatrists (Ballet, Ernest Dupré, Henri Claude, Jean Lhermitte) in the management of shell shock and hysterical manifestations in the fighters [27], but this collaboration rapidly decreased after the war.

In conclusion, it is striking that while Charcot systematically claimed his disinterest in mental disorders, the influence of his work and teaching was critical in shaping the transformation of alienism into academic psychiatry. His strength was to develop a scientific approach to nervous system disorders, emphasizing basic training in neuropathology and neuroanatomy. In parallel to his work for the recognition of emerging neurology, he supported the creation of an academic chair for mental diseases, which was subsequently held by his direct collaborators for nearly half a century. The beginnings of his own neurological school developed around the study of hyste- ria, a condition in which internists and alienists showed little interest. While hysteria was initially considered as a brain disease with a non-visible 'dynamic lesion', the recognition of the importance of mental factors shortly before Charcot's death was also critical in reinforcing the influence of neurology on the evolution of alienism, which had been stuck into organicism after Bayle's discovery of 'arachnitis' in general paresis of the insane. On the other hand, emerging neurology benefited little from established alienism, apart from scarce works overlapping the two fields, by isolated neuropsychiatrists, such as Baillarger and Lasègue. At a time when there presently is a timely renewal of the concepts of neuropsychiatry and psychiatric neurosciences, a fresh look at these early developments of modern neurology and psychiatry may be surprising and helpful.

\section{Acknowledgement}

We thank Olivier Walusinski, MD, for his help in the selection of figures.

\section{References}

1 Rey A, Morvan D: Dictionnaire culturel en langue française. Paris, Dictionnaires Le Robert, 2005.

2 Postel J, Quétel C: Nouvelle histoire de la psychiatrie. Paris, Privat, 1983.

3 Guillain G: J.-M. Charcot, 1825-1893, sa vie, son œuvre. Paris, Masson, 1955.

4 Drèze C: Charcot, 1825-1893. Louvain Méd 2001;120:33-36.

5 Goetz CG, Bonduelle M, Gelfand T: Charcot, Constructing Neurology. New York, Oxford University Press, 1995.

6 Charcot JM: Études pour servir à l'histoire de l'affection décrite sous les noms de goutte asthénique primitive, nodosité des jointures, rhumatisme articulaire chronique (forme primitive), etc. Paris, Bignoux Imprimeur de la Faculté de Médecine, 1853.

7 Briquet P: Traité clinique et thérapeutique de l'hystérie. Paris, Baillière, 1859.

$>8$ Bogousslavsky J, Walusinski O, Veyrunes D: Criminal hypnotism at the Belle Époque: the path traced by Jean-Martin Charcot and Georges Gilles de la Tourette. Eur Neurol 2009;62:193-199.

9 Janet P: Quelques définitions de l'hystérie. Arch Neurol (Paris) 1893;25:417-438 and 26: $1-29$.

10 Janet P: Contribution à l'étude des accidents mentaux chez les hystériques. Paris, Rueff et Cie, 1893
11 Berrios GE: The History of Mental Symptoms. Descriptive Psychopathology since the Nineteenth Century. Cambridge, Cambridge University Press, 1996.

12 Georget P: Névrose; in: Dictionnaire de Médecine: de la physiologie du système nerveux et spécialement du cerveau/recherches sur les maladies nerveuses. Paris, Baillière, 1821.

13 Pinel P: Traité médico-philosophique sur l'aliénation mentale ou la manie. Paris, Richard, Caille et Ravier, 1801.

14 Bayle ALJ: Recherches sur les maladies mentales. Paris, Imprimerie de la Faculté de Médecine, 1822.

15 Fournier JA: Syphilis du cerveau. Paris, Baillière, 1879.

16 Charcot JM, Ball B: Sur la mort subite et la mort rapide à la suite de l'obturation de l'artère pulmonaire par des caillots sanguins, dans les cas de phlegmatia alba dolens et de phlébite oblitérante en général. Paris, Librairie de Victor Masson, 1858.

17 Poirier J, Philippon J: Joseph Babinski, a Biography. Oxford, Oxford University Press, 2008.

18 Bonduelle M: Histoire de la Société Française de Neurologie. Rev Neurol (Paris) 1999; 155:785-801.

19 Baillarger JGF: Du siège de quelques hémorrhagies méningées. Paris, Imprimerie et Fonderie de Rignoux et Cie, 1837.
20 Baillarger JGF: Recherches sur la structure de la couche corticale des circonvolutions du cerveau. Mém Acad Méd Paris 1840;8:149.

21 Oosterhuis JGH: The test of Lasègue; in Koehler P, Bruyn GW, Pearce JMS (eds): Neurological Eponyms. Oxford, Oxford University Press, 2000, pp 148-153.

22 Lasègue C: De la paralysie générale progressive; thèse de concours pour l'agrégation en médecine. Paris, Labé Libraire de la Faculté de Médecine, 1853.

23 Lasègue C: Écrits psychiatriques. Toulouse, Privat, 1971.

24 McHenry LC Jr: Garrison's History of Neurology: Revised and Enlarged with a Bibliography of Classical, Original and Standard Works in Neurology. Springfield, Thomas, 1969.

25 Walusinski O, Bogousslavsky J: À la recherche du neuropsychiatre perdu: Paul Sollier. Rev Neurol (Paris) 2008;164:F239-F247.

26 Bogousslavsky J: Marcel Proust's lifelong tour of the Parisian neurological intelligentsia: from Brissaud and Dejerine to Sollier and Babinski. Eur Neurol 2007;57:129-136.

27 Shepard B: A War of Nerves. Soldiers and Psychiatrists in the Twentieth Century. Cambridge, Harvard University Press, 2001. 